\title{
MANAGEMENT OF GIANT ANEURYSMS
}

\author{
K. DEI-ANANG * - O. HEY*-G. BORGES * - K. SCHURMANN * \\ W. $M U L L E R * *$
}

SUMMARY - Technical aspects and anatomical difficulties involved in the manarement of this entity and the risks associated give giant aneurysms a spectial place in the treatment of aneurysms us a whole. The direct attack needs careful planning and the right choice of instruments, esteclally clips. In spite of the progress in recent years, the rate of mortality is still very hirh. The indirect approach requires in many cases the occlusion of a major cerebral vessel, which in some cases could result in cerebral ischemia. However, by means of extra-intracranial by-pass operation this risk could be reduced. The methui of baloon embolisation has progressed recently. This procedure brings the least discomfort to the patient. Results of this method of treatment must be observed critically for future assessment.

\section{Condut am aneurismas rigantes.}

RESUMO - Os aneurismas gigantes merecem atençăo especial no que se rofere a seus aspectos anatómicos, riscos es princlpalmente, dificuldades técnícas ao seu manuselo. A abordagem de tais aneurismas necessita de planejamento adecuado e, sobremaneira, de materlal apropriado para sua clpagem. A mortalidade ainda permanece alta, apesar dos recentes progressos observados nos ultimos anos. Por outro lado, a abordagem indireta requer, muitas vezes, oclusăo de um vaso cerebral importante, " que pode acarretar isquemia cerebral. Entretanto, por anastomose extra-intracranlana tais liscos podem ser diminuidos. O método de cmbolizachăo por balōes tem-se mostrado eficaz. Este processo oferece menor incómodo ao paciente. Os resultados deste método devem ser observados criteriosamente para melhor avallacăo no futuro.

Giant aneurysms are defined as those larger than $25 \mathrm{~mm}$ in diameter $7,13,14$. In the literature the frequency of occurence of these malformations is rated between $3 \%$ and $6 \%$. In our own material we found giant aneurysms at the rate of $3.8 \%$. According to Koos about $10 \%$ of all giant aneurysms are to be found among children, otherwise giant aneurysms are mostly found between the 3rd and 6th decade of life 7 .

Three illustrative cases are reported in this paper.

\section{CASE RIFPORTS}

Case 1 - MP, female, 17 years old (Fig. 1). Sub-arachnoid haemorrhage (SAH): March, 20, 1986. CT: no trace of SAH. Diagnosis was verified through lumbar puncture (LP). Angiogram: vertebral artery aneurysm after posterior inferior cerebellar artery (PICA) juncture. April, 1986: ligation of the left vertebral artery. Cctober, 1986: angiogram of right vertebral artery showing retrograde filling of the aneurysm. December, 1986: first

- Department of Neurosurgery (Head: Prof. Dr. h. c. K. Schurmann); *" Department of Neuroradiology (Head: Prof. Dr. S. Wende), Univergity Hospital, Mainz (Langenbeckstrasse 1, 6500 Mainz 1, DBR). 


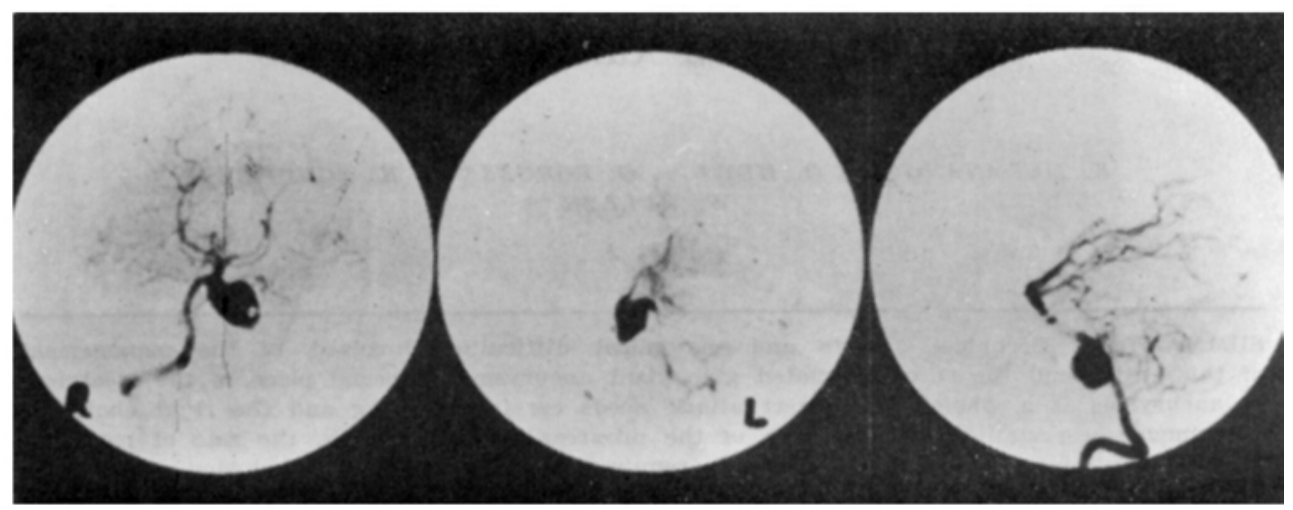

Fig. 1 - Case 1 (MP): aneurysm of the left vertebral artery.

attempt of baloon occlusion falls. Second attempt 6 days later: occlusion of aneurysm with baloon catheter. Anglogram shows patency of the right vertebral artery and basilar artery. Last angiogram (February, 1987): aneurysm 2-3mm in size.

Case 2 - KH, female, 46 years old (Flg. 2). January, 1987: light seizures and diplopia, slight impairment of vision. February, 1987, GP-CT: carotid artery aneurysm infraclinoidal, misinterpreted as meningloma. March, 1987: occlusion of the aneurysm by means of a baloon catheter. April, 1987: anglogram shows no aneurysm. Clinical rest symptoms: diplopia. June, 1987: CT with contrast medium and angiogram show ajeurysm recurrence. Neuroradiological intervention: occlusion of the internal carotid artery. Cerebral blood flow (CBF): sufficient perfusion. Intra-and extracranial occlusion of the internal carotid artery (ICA).

Case 3 - SR, female, 62 years old (Fig. 3). First admission: June, 1987: lack of concentration, drowsiness. CT: 1. clot; 2. hydrocephalus, vintriculo-peritoneal by-pass. Angiography: basilar aneurysm (>25mm) (Copies of angiogra!ns, Inselspital, Bern). Second admission: August, 1987; epileptic seizures, coma, decerebration; she died at 19:00h of the same day.

\section{COMMENTS}

In reviewing the literature and our own material we found out that there does not seem to be a special region of occurence of these giant aneurysms ?. They seem to be in all the areas where small aneurysms are also discovered.

Clinical pattern of behaviour - About $60 \%$ of all giant aneurysms show intra aneurysmal thrombosis. The grade of thrombosis is most likely dependent on: a. reduction of turbulence in the aneurysm sac; $b$. tendency of the thrombus to stick to the aneurysm wall and grow; $c$. the size of the opening between the aneurysm sac and the vessel. Pia suggested, in 1980, quite rightly that giant aneurysms be typed according to the form and size of the thrombus 8 . He put them in 6 main categories. Intracavernous giant aneurysms do not bleed 13,14. The intracranially localised giant aneurysms have a tendency to bleed in $40 \%$ in the supratentorial region and $60 \%$ in the posterior fossa. When they do not bleed these giant aneurysms depending on the localisation will either present with: 1 . cranial nerves symptoms; 2 . tumor-like space occupying symptoms, which are rather typical; 3 . pain in form of headaches due to nerve compressions; 4 . epileptic fits in rare cases. 


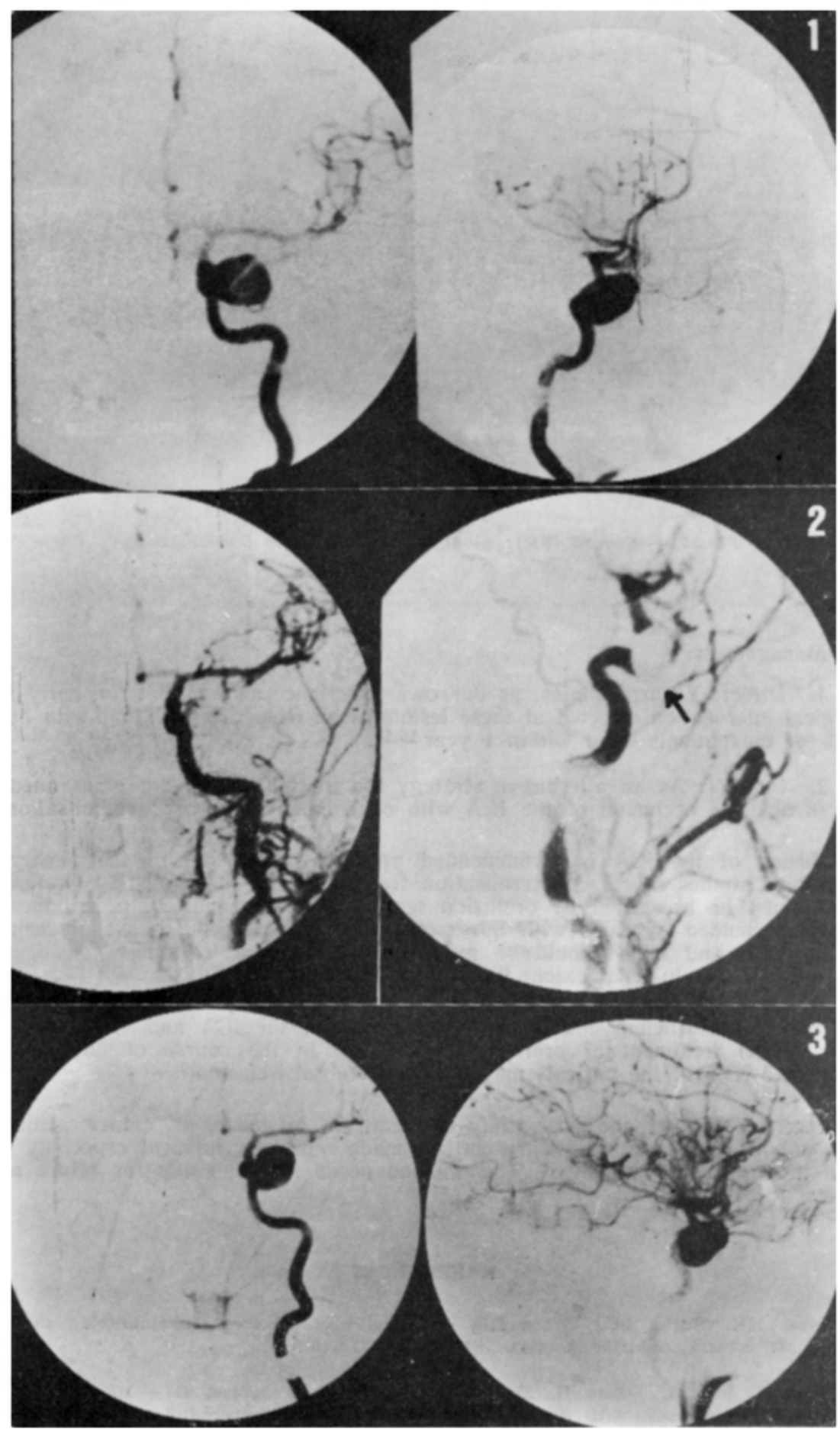

F'ig. 2 - Case $2(K H): 1$. aneurysm of the left carotid artery (infraclinoid); 2. after baloon occlusion; 3. patient presenting with the same aneurysm three months after baloon occlusion. 


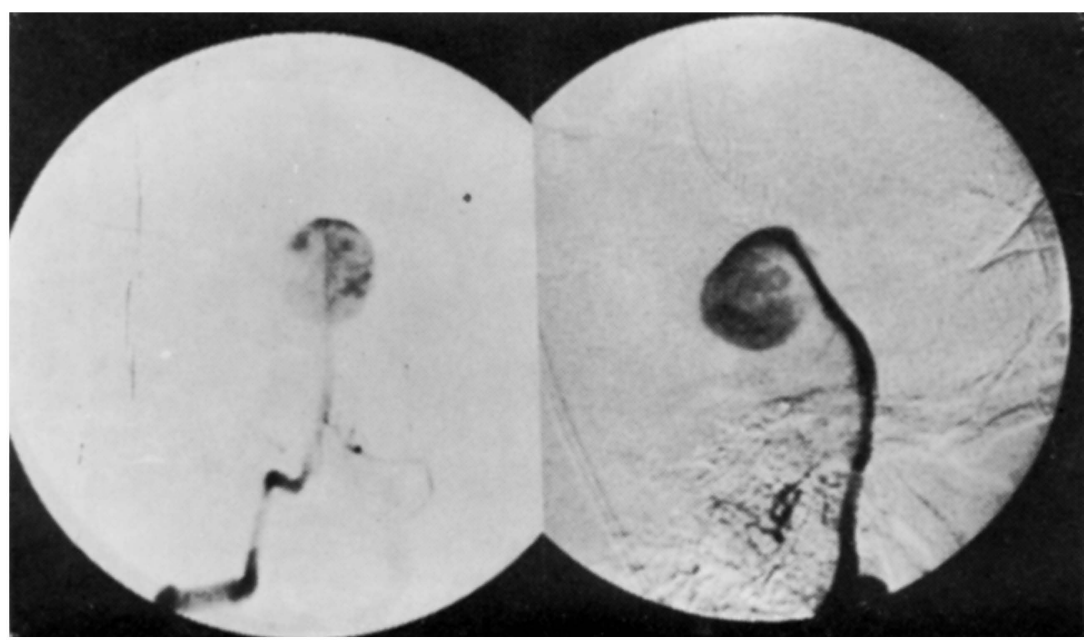

Fig. 3 - Case $3(\mathrm{~S} R)$ : giant aneurysm of the basilar artery.

\section{Management:}

1. Direct: Yasargil states, as our own experience shows, that the early results of surgical intervention directed at these lesions were truly disappointing with between $60-80 \%$ of the patients dead within 1 year 13,14 .

2. Indirect: As an alternative strategy the treatment of these giant aneurysms would involve the occlusion of the ICA with or without by-pass or embolisation 10:

a. Occlusion of the ICA is recommended proximal and distal of the aneurysm if ongiographic studies reveal collateralisation from the other hemisphere. Occlusion of the ICA must be preceeded by occlusion tests either by means of a balooncatheter or as recommended by Koos with Silverstone-clip 7. During the phase of temporary occlusion $\mathrm{CBF}$ and EEG should be monitored to be able to follow the behaviour of the brain to see to what extent the patient tolerates the occlusion 1,5,11,12.

b. In case of insufficient collateralisation ligation of the ICA and extra-intracranial by-pass is the treatment of preference $6,7,11,13,14$. In the course of and after this procedure $15-30 \%$ of the patients may develop cerebral ischemia 3 .

c. In recent years yet another variety of treatment by means of catheterisation and baloon embolisation of giant aneurysms has made rapid development especially in the field of invasive neuroradiology. This method needs further study for future assessment 2,9 .

\section{REFERENCES}

1. Chlanpa KH, Burke SR, Young RR - Results of electroencephalographic monitoring after 367 cerotid endarterectomies. Stroke 10:381, 1979.

2. Debrun G, Fox A, Drake G, Peerless S, Girvin J, Ferguson G - Giant unclippable aneurysms: treatment with detachable balloons. Am $J$ Neuroradiol 2:167, 1981.

3 Diaz FG, Ausman JI, Pearce JG - Ischemic complications after internal carotid artery occlusion and extracranial-intracranial anastomosis. Neurosurgery 10:563, 1982. 
4. German WJ, Black SPW - Cervical ligation for internal carotid aneurysms. J Neurosurg 23:572, 1965.

5. Giannotta SL McGillicuddy JE, KRindt GW - Gradual carotid artery occlusion in the treatment of inaccessible carotid artery aneurysms. Neurosurgery 6:417, 1979.

6. Hopkins LN, Grand W - Extracranial-intracranial arterial bypass in the treatment of aneurysms of the carotid and middle cerebral arteries. Neurosurgery 5:21, 1979.

7. Koos WT, Ferneczky A, Schuster H, Vorkapic $\mathbf{P}-$ Zerebrale Riesenaneurysmen. In Der zerebrale Nitfall. Urban \& Schwarzenberg, München, 1985, pg 163.

8. Pia HW - Large and giant aneurysms. Neurosurg Rev 3:7, 1980.

9. Swann KW, Heros RC, Debrun GM, Nelson C - Inadvertent MCA embolism by a detachable ballcon: management by embolectomy. Case report. Neurosurgery 64:309, 1986.

10. Swearingen B, Heros RC - Common carotid occlusion for urclippable carotid aneurysms: an old but still effective operation. J Neurosurg 21:288, 1987.

11. Ulrich $P$, Meining G, Ludwig B, Prohl U, Krämer G - Die traumatische sinus-cavernosus-Fistal - Cerebrale Hämodynamik prä- und postopeiativ. Paper presented at 21. Jahrestagung \&Deutsche Gesellschaft für Hirntraumatologie und klinische Hirnpathologie», Manuhelm, 1985.

12 Ulrich P, Ludwig B, Suss $W$, Melnig G - nrCBF- and $\mathrm{EE}(\mathrm{y}$-monitoring during probatory balloon occlusion of the internal carotid artery. Advances in Neurosurgery, Vol 13. Springer, Perlin, 1985, pg 317.

13. Yasargil MC - Microneurosurgery, Vol 1. Thieme, Stuttgart, 1984.

14. Yasarg1l MG - Microneurosurgery, Vol XI, Thieme, Stuttgart, 1981 